Case Reports
in Dermatology
Case Rep Dermatol 2021;13:89-97

DOI: 10.1159/000512289

Published online: February 4, 2021

(C) 2021 The Author(s)

Published by S. Karger AG, Basel

www.karger.com/cde

This article is licensed under the Creative Commons Attribution-NonCommercial 4.0 International License (CC BY-NC) (http://www.karger.com/Services/OpenAccessLicense). Usage and distribution for commercial purposes requires written permission.

\title{
Primary Cutaneous Cryptococcosis due to Cryptococcus neoformans in an Immunocompetent Host Treated with Itraconazole and Drainage: Case Report and Review of the Literature
}

\author{
Elizabeth Gaviria Morales ${ }^{a}$ Marco Guidi $^{b, c}$ Tomas Peterka ${ }^{b}$ d \\ Andrea Rabufetti ${ }^{a}$ Roland Blum ${ }^{\mathrm{e}}$ Carlo Mainetti ${ }^{\mathrm{a}}$ \\ aDepartment of Dermatology, Ente Ospedaliero Cantonale, Bellinzona, Switzerland; \\ bDepartment of Orthopedics and Traumatology, Ente Ospedaliero Cantonale, \\ Bellinzona, Switzerland; 'Department of Plastic Surgery and Hand Surgery, University \\ Hospital Zurich, Zurich, Switzerland; dDepartment of Orthopedics and Traumatology, \\ Santa Chiara Clinic, Locarno, Switzerland; eDepartment of Dermatology, Inselspital Bern \\ University Hospital, University of Bern, Bern, Switzerland
}

\section{Keywords}

Cryptococcus neoformans - Primary cutaneous cryptococcosis - Immunocompetent host .

Ulcer $\cdot$ Itraconazole

\begin{abstract}

\begin{tabular}{ll}
\hline & Elizabeth Gaviria Morales \\
Department of Dermatology, Ente Ospedaliero Cantonale & Via Ospedale 12 \\
CH-6500 Bellinzona (Switzerland) \\
gaviriamora@yahoo.it
\end{tabular}
\end{abstract}

Cryptococcus neoformans is an opportunistic germ, usually causing infections in immunocompromised patients. The main sources of infection with $C$. neoformans are excrement from birds, decomposing wood, fruit, and vegetables. Primary cutaneous cryptococcosis (PCC) is a clinical 


\section{Case Reports in Dermatology}

\begin{tabular}{l|l}
\hline Case Rep Dermatol 2021;13:89-97 \\
\hline DOI: 10.1159/000512289 & $\begin{array}{l}\text { ( 2)21 The Author(s). Published by S. Karger AG, Basel } \\
\text { www.karger.com/cde }\end{array}$ \\
\hline
\end{tabular}

Gaviria Morales et al.: A Primary Cutaneous Cryptococcosis in an Immunocompetent Woman

entity, differing from secondary cutaneous cryptococcosis and systematic infection. We report the case of an immunocompetent 60-year-old woman with PCC due to C. neoformans in her right thumb. She reported an accidental injury caused by a rose thorn while she was gardening. Clinical examination showed the presence of an erythematous ulcerated nodule with elevated borders, suppuration, and central necrosis. Skin histology examination showed cutaneous and subcutaneous fibrinoid necrosis with bleeding, abscess, neutrophil-rich cellular infiltration, and the presence of PAS-, Grocott- and mucin-positive spores. The mycological culture showed milky and creamy colonies of $C$. neoformans after 3 days. As there was no previous history of pulmonary cryptococcosis, we diagnosed PPC. We treated the patient surgically with accurate debridement of nonvital tissues in the right thumb. In addition, we started itraconazole treatment 100 mg twice daily for 6 months, which led to rapid clinical improvement without relapse. $P C C$ is a rare infection that can present with quite unspecific clinical pictures including acneiform lesions, purpura, vesicles, nodules, abscesses, ulcers, granulomas, pustules, draining sinuses, and cellulitis. Prolonged systemic antifungal therapy is necessary in order to get a healing result without relapse. We summarize all the cases of PCC in immunocompetent patients published so far in the literature.

(C) 2021 The Author(s)

Published by S. Karger AG, Basel

\section{Introduction}

Cryptococcus neoformans is an opportunistic germ, usually causing infections in immunocompromised patients. The main sources of infection with $C$. neoformans are excrements from birds, decomposing wood, fruit, and vegetables. Primary cutaneous cryptococcosis (PCC) is a clinical entity, differing from secondary cutaneous cryptococcosis and systemic infection [1-4].

We present the case of an immunocompetent woman with PCC due to C. neoformans in her right thumb, together with a review of the current literature.

\section{Case Report}

A 60-year-old woman presented to our department with a 4-day-old swelling and erythema around the right thumb, having already been treated with cefuroxime for 3 days by her general practitioner without any improvement. She reported an accidental injury 5 days previously caused by a rose thorn while she was gardening. The patient was in good health and had not taken any immunosuppressives or other drugs. There was no history of any contact with avian excretions, pigeons, or other animals, and she denied recent travelling.

On dermatological examination, we found an erythematous ulcerated nodule with elevated borders, suppuration, and central necrosis (Fig. 1a). There was no regional lymphadenopathy and no other skin involvement. Routine blood examination, a total lymphocyte count, and blood immunoglobulins were normal. The C-reactive protein level was $55 \mathrm{mg} / \mathrm{L}$, while the erythrocyte sedimentation rate was $77 \mathrm{~mm} / \mathrm{h}$. HIV and hepatitis B and C serology results 


\section{Case Reports in Dermatology}

Case Rep Dermatol 2021;13:89-97

DOI: $10.1159 / 000512289$

(C) 2021 The Author(s). Published by S. Karger AG, Basel www.karger.com/cde

Gaviria Morales et al.: A Primary Cutaneous Cryptococcosis in an Immunocompetent Woman

were negative. X-rays of the chest and the right thumb were also normal. At first, we suspected a bacterial or herpetic infection, but the lesion swab cultures for bacteria and the PCR examination for Mycobacterium as well as herpes simplex virus were also negative. We performed a biopsy for histological examination from skin lesion fragments after surgical debridement, removing necrotic tissue from the right thumb (Fig. 1b). The histology picture showed cutaneous and subcutaneous fibrinoid necrosis with bleeding, an abscess forming, neutrophil-rich cellular infiltration, and the presence of multiple PAS-, colloid iron- and mucin-positive spores (Fig. 2).

A swab sample from the lesion was inoculated on tubes with slide Sabouraud chloramphenicol and $\mathrm{BBL}^{\mathrm{TM}} \mathrm{Mycose}^{\mathrm{TM}}$ agar and incubated at 30 and $35^{\circ} \mathrm{C}$. On day 3, milky and creamy colonies of $C$. neoformans started to grow on the Mycosel agar at $30^{\circ} \mathrm{C}$. Then, colonies were transferred to an agar plate (Sabouraud chloramphenicol agar and ChromID Candida; bioMérieux) and incubated at the same temperatures. Microscopical examination showed globoseto-ovoid, budding, yeast-like cells. Identification of $C$. neoformans was possible with matrixassisted laser desorption ionization-time of flight mass spectrometry [5]. We diagnosed PPC in an immunocompetent patient.

For antifungal susceptibility assessment, we used the European Committee on Antimicrobial Susceptibility Testing (EUCAST) guidelines [6]. The antifungals tested were amphotericin $(0.5 \mathrm{mg} / \mathrm{L})$, ketoconazole $(0.64 \mathrm{mg} / \mathrm{L})$, itraconazole $(0.121 \mathrm{mg} / \mathrm{L}), 5$-fluorocytosine $(1 \mathrm{mg} / \mathrm{L})$, voriconazole $(0.064 \mathrm{mg} / \mathrm{L})$, and fluconazole $(4 \mathrm{mg} / \mathrm{L})$.

In addition to the debridement, we performed two lateral incisions in a sterile area next to the medial and lateral perionychium to drain collections. The necrotic epidermis of the fingertip was completely detached in its superficial layer. After the surgical debridement, the patient needed periodic dressing. Complementary to surgical therapy, we started treatment with itraconazole $100 \mathrm{mg} / 12 \mathrm{~h}$ for 6 months, with rapid clinical improvement and without relapse to infection during the 6-month follow-up after the systemic antifungal therapy (Fig. 3).

\section{Discussion}

The genus Cryptococcus comprises the two clinically relevant species $C$. neoformans and C. gattii among few other species. Whilst $C$. neoformans is mainly observed in patients with immunodeficiency and rarely in immunocompetent patients, C. gattii is found in immunocompetent patients in endemic areas [4,5]. The main sources of infection with $C$. neoformans are excrements from pigeons or other birds, as well as decomposing wood, fruit, and vegetables [3]. C. gattii is not present in birds' feces, but it inhabits a variety of arboreal species, including several types of eucalyptus tree [1].

PCC is a separate clinical entity distinct from secondary cutaneous cryptococcosis, the latter of which mainly occurs in patients with lung cryptococcosis and systemic infection. Generally, secondary cutaneous cryptococcosis infection occurs in immunocompromised hosts and rarely in immunocompetent hosts $[7,8]$. PCC is a rare infection that can present with quite unspecific clinical pictures, including acneiform lesions, purpura, vesicles, nodules, abscesses, ulcers, granulomas, pustules, draining sinuses, and cellulitis $[9,10]$.

\section{Karger'=}




\section{Case Reports in Dermatology}

Case Rep Dermatol 2021;13:89-97

DOI: $10.1159 / 000512289$

(C) 2021 The Author(s). Published by S. Karger AG, Basel www.karger.com/cde

Gaviria Morales et al.: A Primary Cutaneous Cryptococcosis in an Immunocompetent Woman

For a long time, the existence of PCC as a clinical entity had been in doubt. In the year 1972, Noble and Fajardo [10] proposed three diagnostic criteria for PCC (Table 1). We recorded the features of both our case and the 21 additional cases of PCC in immunocompetent patients due to $C$. neoformans in the last 20 years [11-27]. We excluded cases of PCC due to $C$. gattii, which is well known to be a cause of infection of immunocompetent patients in endemic areas [1]. Our case and the other cases reviewed fulfill all diagnostic criteria by Noble and Fajardo (Table 1).

Parameters such as year of diagnosis, age, gender, predisposing factors, clinical manifestation(s), treatment prescribed, and outcome are reported separately (Table 2). The male sex was more affected (17/22 cases). The patients' ages ranged from 10 to 81 years (mean 60.13). The most frequent site of infection was the forearm $(9 / 22)$, followed by the hand and fingers $(6 / 22)$. Clinical manifestations consisted of nodules, sometimes ulcerated $(9 / 22)$, infiltrative lesions $(4 / 22)$, plaques $(3 / 22)$, papules $(1 / 22)$, cellulitis $(2 / 22)$, granulomata $(1 / 22)$, erythema with edema (1/22), and lipoma-like swelling (1/22) (Table 2). Only in 10 of the 22 patients was there a history of trauma prior to infection. Nine of the 22 cases reported contact with avian excreta. In 8 of the 22 cases, the source of infection was totally unknown.

Concerning the kind of inflammation, it should be kept in mind that the different wellknown patterns or stages of cutaneous cryptococcosis (suppurative, gelatinous, and granulomatous) are reflecting the dynamic process and ability of the hosts' immune system to get rid of the infectious agents, which usually takes a few years. As PCC is a rare event in immunocompetent patients, unlike in systemic disease, treatment in this setting is not well defined.

Nonetheless, itraconazole was effective in curing the lesions in 10/22 cases; 8 of these cases were treated with itraconazole only, whereas in 1 case itraconazole was the final treatment after switching from fluconazole (case 3) and in 1 case itraconazole was the final treatment after previous treatment with fluconazole and amphotericin (case 5).

Fluconazole alone was administered in $11 / 22$ cases, but healing could only be achieved in 9 of these cases; in the remaining 2 cases (cases 3 and 5), it was necessary to switch to itraconazole and in 1 case healing was achieved after combined treatment with fluconazole and amphotericin (case 15). The range of itraconazole dosage was $100-400 \mathrm{mg} /$ day for a duration of 3-6 months. The range of fluconazole dosage was $200-800 \mathrm{mg} /$ day for a duration of 2 weeks to 1 year.

Two of the 22 cases reviewed, including ours, had also undergone surgical debridement before being given itraconazole. One patient (case 18) healed without treatment, and in 1 case the treatment is unknown (case 2).

Despite the limited number of cases, itraconazole seems to be the most effective treatment. Fluconazole showed high efficacy as well; however, in 2 cases, treatment had to be switched to itraconazole as the final treatment. In our patient, surgical debridement in combination with a prolonged therapy with itraconazole was very effective in clearing the lesions within 6 months (Fig. 3). 


\section{Case Reports in Dermatology}

\section{Conclusion}

PCC is a rare primary infection limited to the skin which can heal without further systemic dissemination in individuals with a competent immune system. Based on our experience and the reviewed cases, itraconazole seems to be the most effective treatment.

\section{Statement of Ethics}

The research was conducted ethically in accordance with the World Medical Association Declaration of Helsinki. The patient has given written informed consent for the publication of this case report (including images).

\section{Conflict of Interest Statement}

The authors have no conflicts of interest to declare.

\section{Funding Sources}

This case report did not receive funding from third parties.

\section{Author Contributions}

All authors have made substantial contributions to all of the following: (1) the conception and design of the review and the analysis and interpretation of data; (2) drafting the article or revising it critically for important intellectual content; and (3) final approval of the version to be submitted.

\section{References}

1 Pau M, Lallai C, Aste N, Aste N, Atzori L. Primary cutaneous cryptococcosis in an immunocompetent host. Mycoses. 2010 May;53(3):256-8.

2 Revenga F, Paricio JF, Merino FJ, Nebreda T, Ramírez T, Martínez AM. Primary cutaneous cryptococcosis in an immunocompetent host: case report and review of the literature. Dermatology. 2002;204(2):145-9.

3 Neuville S, Dromer F, Morin O, Dupont B, Ronin O, Lortholary O; French Cryptococcosis Study Group. Primary cutaneous cryptococcosis: a distinct clinical entity. Clin Infect Dis. 2003 Feb;36(3):337-47.

4 Du L, Yang Y, Gu J, Chen J, Liao W, Zhu Y. Systemic Review of Published Reports on Primary Cutaneous Cryptococcosis in Immunocompetent Patients. Mycopathologia. 2015 Aug;180(1-2):19-25.

5 Firacative C, Trilles L, Meyer W. MALDI-TOF MS enables the rapid identification of the major molecular types within the Cryptococcus neoformans/C. gattii species complex. PLoS One. 2012;7(5):e37566.

6 Rodríguez-Tudela JL, Arendrup MC, Cuenca-Estrella M, Donnelly JP, Lass-Flörl C. EUCAST breakpoints for antifungals. Drug News Perspect. 2010 Mar;23(2):93-7. 


\section{Case Reports in Dermatology}

\begin{tabular}{l|l} 
Case Rep Dermatol 2021;13:89-97 \\
\hline DOI: 10.1159/000512289 & $\begin{array}{l}\text { @ 2021 The Author(s). Published by S. Karger AG, Basel } \\
\text { www.karger.com/cde }\end{array}$
\end{tabular}

Gaviria Morales et al.: A Primary Cutaneous Cryptococcosis in an Immunocompetent Woman

7 Lenz D, Held J, Goerke S, Wagner D, Tintelnot K, Henneke P, et al. Primary cutaneous cryptococcosis in an eight-year-old immunocompetent child: how to treat? Klin Padiatr. 2015 Jan;227(1):41-4.

8 Christianson JC, Engber W, Andes D. Primary cutaneous cryptococcosis in immunocompetent and immunocompromised hosts. Med Mycol. 2003 Jun;41(3):177-88.

9 Dimino-Emme L, Gurevitch AW. Cutaneous manifestations of disseminated cryptococcosis. J Am Acad Dermatol. 1995 May;32(5 Pt 2):844-50.

10 Noble RC, Fajardo LF. Primary cutaneous cryptococcosis: review and morphologic study. Am J Clin Pathol. 1972 Jan;57(1):13-22.

11 Anderson DJ, Schmidt C, Goodman J, Pomeroy C. Cryptococcal disease presenting as cellulitis. Clin Infect Dis. 1992 Mar;14(3):666-72.

12 Botnaru V, Rusu D, Haidarlî I, Munteanu 0, Corlateanu A. Cryptococcosis - a common fungal infection in immunosuppressed patient [in Romanian]. Pneumologia. 2014 Jul-Sep;63(3):156, 159-63.

13 Al-Marzooq YM, Chopra R, Al-Mommatten MI, Younis M, Al-Mulhim AS, Al-Hussini H. Fine-needle aspiration diagnosis of primary cutaneous cryptococcosis in an immunocompetent patient: a case report. Diagn Cytopathol. 2005 Apr;32(4):219-21.

14 Xiujiao X, Ai'e X. Two cases of cutaneous cryptococcosis. Mycoses. 2005 Jul;48(4):238-41.

15 Kumar P, Saran RK, Gondal R, Malhotra V. Smear morphology of cryptococcosis presenting as a subcutaneous swelling in healthy adults: a report of three cases. Cytopathology. 2005 Jun;16(3):143-6.

16 Yuge S, Bastazini Júnior I, Coelho MC, Soares CT. Cutaneous cryptococcosis in an immunocompetent host. Acta Derm Venereol. 2006;86(2):165-6.

17 Allegue F, de Lis MP, Pérez-Alvarez R. Primary cutaneous cryptococcosis presenting as a whitlow. Acta Derm Venereol. 2007;87(5):443-4.

18 Werchniak AE, Baughman RD. Primary cutaneous cryptococcosis in an elderly man. Clin Exp Dermatol. 2004 Mar;29(2):159-60.

19 Nasser N, Nasser Filho N, Vieira AG. Primay cutaneous cryptococcosis in an immunocompetent patient. An Bras Dermatol. 2011 Nov-Dec;86(6):1178-80.

20 Spiliopoulou A, Anastassiou ED, Christofidou M. Primary cutaneous cryptococcosis in immunocompetent hosts. Mycoses. 2012 Mar;55(2):e45-7.

21 Marques SA, Bastazini I Jr, Martins AL, Barreto JA, Barbieri D’Elia MP, Lastória JC, et al. Primary cutaneous cryptococcosis in Brazil: report of 11 cases in immunocompetent and immunosuppressed patients. Int J Dermatol. 2012 Jul;51(7):780-4.

22 Narváez-Moreno B, Bernabeu-Wittel J, Zulueta-Dorado T, Conejo-Mir J, Lissen E. Primary cutaneous cryptococcosis of the penis. Sex Transm Dis. 2012 Oct;39(10):792-3.

23 Jackson NA, Herring DB. Primary capsule-deficient cutaneous cryptococcosis in a sporotrichoid pattern in an immunocompetent host. Cutis. 2015 Jul;96(1):E26-9.

24 Hyde K, Warren D, Gavino AC. Primary cutaneous cryptococcal infection with subsequent erythema nodosum in a 10-year-old immunocompetent girl. JAAD Case Rep. 2016 Dec;2(6):494-6.

25 Henderson GP, Dreyer S. Ulcerative cellulitis of the arm: a case of primary cutaneous cryptococcosis. Dermatol Online J. 2018 Feb;24(2):24.

26 Twede JV, Peters KM. Primary cutaneous cryptococcosis in an immunocompetent Iraq War veteran. Cutis. 2018 Nov;102(5):E30-1.

27 Beatson M, Harwood M, Reese V, Robinson-Bostom L. Primary cutaneous cryptococcosis in an elderly pigeon breeder. JAAD Case Rep. 2019 May;5(5):433-5. 


\section{Case Reports in Dermatology}

\begin{tabular}{l|l}
\hline Case Rep Dermatol 2021;13:89-97 \\
\hline DOI: 10.1159/000512289 & $\begin{array}{l}\text { (c) 2021 The Author(s). Published by S. Karger AG, Basel } \\
\text { www.karger.com/cde }\end{array}$ \\
\hline
\end{tabular}

Gaviria Morales et al.: A Primary Cutaneous Cryptococcosis in an Immunocompetent Woman

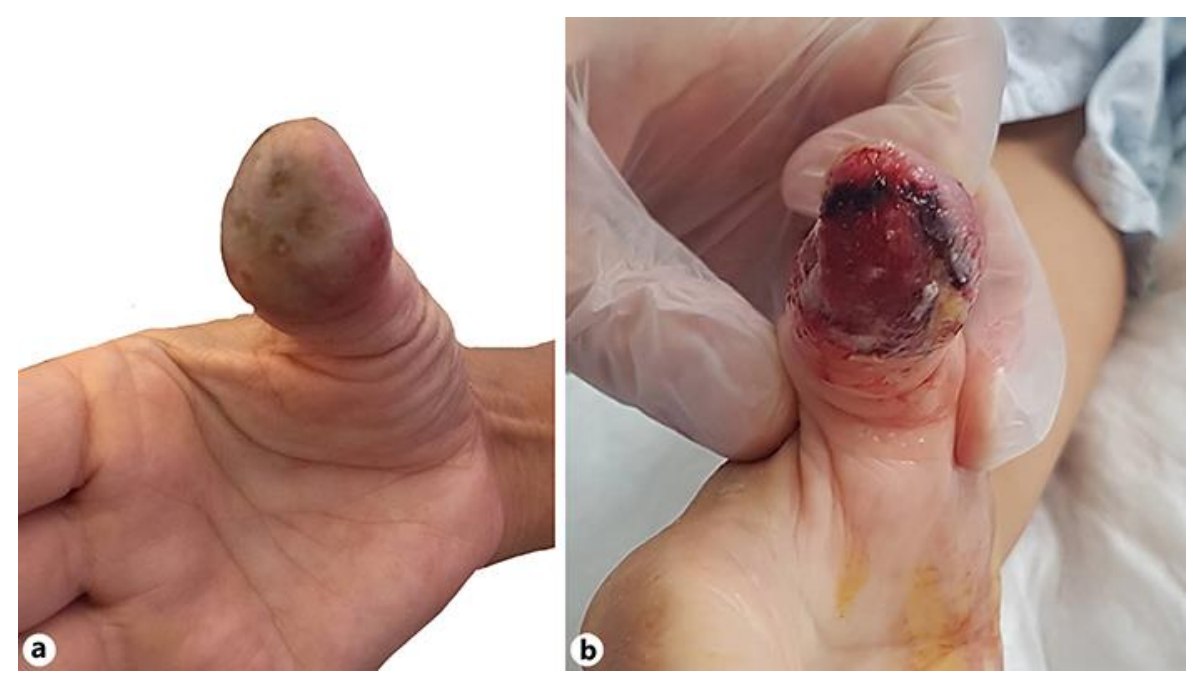

Fig. 1. a Initial cutaneous necrosis of the right thumb of a 60-year-old woman. b Two days after hospitalization and after surgical debridement of the necrotic parts of the right thumb.

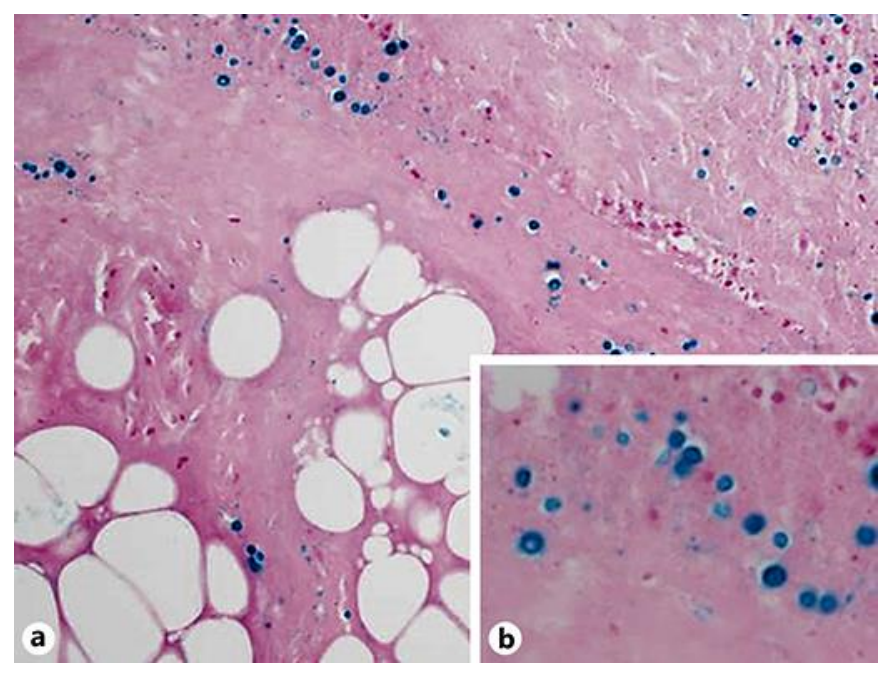

Fig. 2. a Histology of the surgical debridement of the right thumb. Fibrinoid-necrotic, subcutaneous adipose tissue with hemorrhage and evidence of mucin-positive spores. Colloidal iron. $\times 200$. $\mathbf{b}$ The mucin-positive spores had a halo or a slime capsule. Colloidal iron. $\times 400$. 


\section{Case Reports in Dermatology}

Case Rep Dermatol 2021;13:89-97

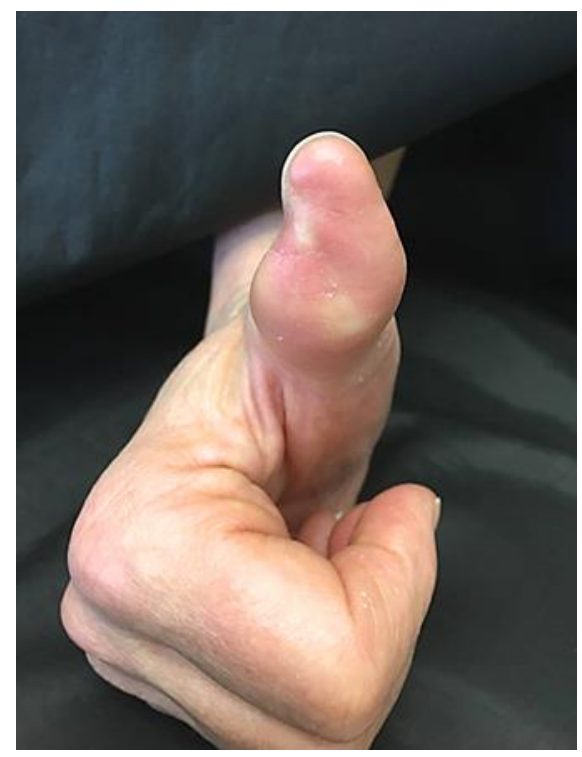

Fig. 3. Right thumb after 6 months of itraconazole treatment $100 \mathrm{mg}$ twice daily. Note the loss of substance to the fingertip.

Table 1. Diagnostic clinical criteria for primary cutaneous cryptococcosis according to Noble and Fajardo [10]

\begin{tabular}{ll}
$\frac{1}{2}$ & Absence of infection in other organs \\
\hline 3 & $\begin{array}{l}\text { Absence of extracutaneous infection within } 4 \text { weeks after the pri- } \\
\text { mary cutaneous cryptococcosis diagnosis }\end{array}$
\end{tabular}

Table 2. Demographic and clinical data on immunocompetent patients with primary cutaneous cryptococcosis

\begin{tabular}{|c|c|c|c|c|c|c|c|}
\hline $\begin{array}{l}\text { Case } \\
\text { No. }\end{array}$ & Study [Ref.] & $\begin{array}{l}\text { Year of } \\
\text { report }\end{array}$ & $\begin{array}{l}\text { Age, } \\
\text { years/ } \\
\text { gender }\end{array}$ & $\begin{array}{l}\text { Predisposing } \\
\text { factor(s) }\end{array}$ & Clinical manifestation(s) & $\begin{array}{l}\text { Treatment (drug/daily dose/ } \\
\text { duration of treatment) }\end{array}$ & Outcome \\
\hline 1 & $\begin{array}{l}\text { Revenga } \\
\text { et al. [2] }\end{array}$ & 2002 & $46 / \mathrm{M}$ & Trauma & Cellulitis in third right finger & $\begin{array}{l}\text { ITZ } 200 \mathrm{mg} / \mathrm{d} \text {, } \\
10 \text { months + surgical excision + ITZ } 200 \\
\text { mg/d } 1 \text { month }\end{array}$ & Cured \\
\hline 2 & $\begin{array}{l}\text { Al-Marzooq } \\
\text { et al. [13] }\end{array}$ & 2005 & $43 / \mathrm{M}$ & Unknown & $\begin{array}{l}\text { Nodules on forehead and in } \\
\text { lumbar region }\end{array}$ & Unknown & Cured \\
\hline
\end{tabular}

\section{Karger'=}




\section{Case Reports in Dermatology}

Case Rep Dermatol 2021;13:89-97 (c) 2021 The Author(s). Published by S. Karger AG, Basel www.karger.com/cde

Gaviria Morales et al.: A Primary Cutaneous Cryptococcosis in an Immunocompetent

Woman

\begin{tabular}{|c|c|c|c|c|c|c|c|}
\hline 3 & $\begin{array}{l}\text { Xiujiao } \\
\text { and Ai'e [14] }\end{array}$ & 2005 & $35 / \mathrm{M}$ & Unknown & Painless nodules on thigh & $\begin{array}{l}\text { ITZ } 400 \mathrm{mg} / \mathrm{d}, 3 \text { days, then FCZ } 200 \mathrm{mg} / \mathrm{d} \\
\text { for } 14 \text { days, then ITZ } 200 \mathrm{mg} / \mathrm{d} \text { for } 2 \\
\text { months }\end{array}$ & Cured \\
\hline 4 & $\begin{array}{l}\text { Kumar } \\
\text { et al. [15] }\end{array}$ & 2005 & $40 / \mathrm{M}$ & Unknown & $\begin{array}{l}\text { Painless subcutaneous lipoma- } \\
\text { like swelling of abdominal flank }\end{array}$ & $\begin{array}{l}\text { FCZ (dosage and time not } \\
\text { reported) }\end{array}$ & Cured \\
\hline 5 & $\begin{array}{l}\text { Yuge } \\
\text { et al. [16] }\end{array}$ & 2006 & $75 / \mathrm{F}$ & Unknown & Erythematous plaque on forearm & $\begin{array}{l}\text { FCZ } 400 \mathrm{mg} / \mathrm{d}, 3 \text { months, then AMB } 50 \mathrm{mg} \text {, } \\
3 \text { times a week for } 15 \text { weeks, then ITZ } 200 \\
\mathrm{mg} / \mathrm{d} \text { for } 6 \text { months }\end{array}$ & Cured \\
\hline 6 & $\begin{array}{l}\text { Allegue } \\
\text { et al. [17] }\end{array}$ & 2007 & $71 / \mathrm{M}$ & Unknown & $\begin{array}{l}\text { Painful erythematous and } \\
\text { edematous, whitlow-like skin of } \\
\text { right thumb }\end{array}$ & $\begin{array}{l}\text { FCZ } 400 \mathrm{mg} / \mathrm{d}, 1 \text { month, then } 200 \mathrm{mg} / \mathrm{d}, 2 \\
\text { months }\end{array}$ & Cured \\
\hline 7 & $\begin{array}{l}\text { Pau } \\
\text { et al. [1] }\end{array}$ & 2010 & $58 / \mathrm{M}$ & Trauma & $\begin{array}{l}\text { Growing nodule from hand to } \\
\text { forearm }\end{array}$ & ITZ $200 \mathrm{mg} / \mathrm{d}$ for 4 months & Cured \\
\hline 8 & $\begin{array}{l}\text { Werchniak } \\
\text { and } \\
\text { Baughman } \\
{[18]}\end{array}$ & 2010 & $81 / \mathrm{M}$ & $\begin{array}{l}\text { Trauma and } \\
\text { contact with avian ex- } \\
\text { creta }\end{array}$ & Asymptomatic nodule on forearm & ITZ $200 \mathrm{mg} / \mathrm{d}$ for 3 months & Cured \\
\hline 9 & $\begin{array}{l}\text { Nasser } \\
\text { et al. [19] }\end{array}$ & 2011 & $67 / \mathrm{M}$ & $\begin{array}{l}\text { Trauma and } \\
\text { contact with avian ex- } \\
\text { creta }\end{array}$ & Itching nodule, ulceration on forearm & FCZ $450 \mathrm{mg} / \mathrm{d}$ for 40 days & Cured \\
\hline 10 & $\begin{array}{l}\text { Spiliopoulou } \\
\text { et al. [20] }\end{array}$ & 2012 & $58 / \mathrm{M}$ & Unknown & Granulomatous lesion with ulcer on hand & FCZ 200 mg/d, 2 weeks & Cured \\
\hline 11 & $\begin{array}{l}\text { Spiliopoulou } \\
\text { et al. [20] }\end{array}$ & 2012 & $67 / \mathrm{F}$ & $\begin{array}{l}\text { Contact with avian ex- } \\
\text { creta }\end{array}$ & -Painful cellulitis with ulceration on finger & $\begin{array}{l}\text { Surgery and } 2 \text { weeks of } 200 \mathrm{mg} / \mathrm{d} \mathrm{FCZ,} \\
\text { then } 2 \text { weeks of FCZ } 100 \mathrm{mg} / \mathrm{d}\end{array}$ & Cured \\
\hline 12 & $\begin{array}{l}\text { Marques } \\
\text { et al. [21] }\end{array}$ & 2012 & $72 / \mathrm{M}$ & $\begin{array}{l}\text { Trauma and } \\
\text { contact with avian ex- } \\
\text { creta }\end{array}$ & $\begin{array}{l}\text { Infiltrative or tumoral-aspect lesion of fore- } \\
\text { arm }\end{array}$ & ITZ $200 \mathrm{mg} / \mathrm{d}$ for 3 months & Cured \\
\hline 13 & $\begin{array}{l}\text { Marques } \\
\text { et al. [21] }\end{array}$ & 2012 & $79 / \mathrm{M}$ & $\begin{array}{l}\text { Trauma and } \\
\text { contact with avian ex- } \\
\text { creta }\end{array}$ & $\begin{array}{l}\text { Infiltrative or tumoral-aspect lesion of arm } \\
\text { - and forearm }\end{array}$ & FCZ $300 \mathrm{mg} / \mathrm{d}$ for 2 months & Cured \\
\hline 14 & $\begin{array}{l}\text { Marques } \\
\text { et al. [21] }\end{array}$ & 2012 & $70 / \mathrm{M}$ & Unknown & $\begin{array}{l}\text { Infiltrative or tumoral-aspect lesion of fore- } \\
\text { arm }\end{array}$ & ITZ $100 \mathrm{mg} / \mathrm{d}$ for 3 months & Cured \\
\hline 15 & $\begin{array}{l}\text { Marques } \\
\text { et al. [21] }\end{array}$ & 2012 & $75 / \mathrm{F}$ & $\begin{array}{l}\text { Trauma and } \\
\text { contact with avian ex- } \\
\text { creta }\end{array}$ & $\begin{array}{l}\text { Infiltrative or tumoral-aspect lesion of fore- } \\
\text { arm }\end{array}$ & $\begin{array}{l}\text { FCZ } 400 \mathrm{mg} / \mathrm{d}, 3 \text { months, + AMB total } \\
2,250 \mathrm{mg}\end{array}$ & Cured \\
\hline 16 & $\begin{array}{l}\text { Narváez-Moreno } \\
\text { et al. [22] }\end{array}$ & 2012 & $66 / \mathrm{M}$ & $\begin{array}{l}\text { Contact with avian ex- } \\
\text { creta }\end{array}$ & $\begin{array}{l}\text {-Asymptomatic nodules, ulcer and molluscum- } \\
\text { like papules on penis }\end{array}$ & ITZ $400 \mathrm{mg} / \mathrm{d}$ for 3 months & Cured \\
\hline 17 & $\begin{array}{l}\text { Jackson and } \\
\text { Herring [23] }\end{array}$ & 2015 & $73 / \mathrm{M}$ & Trauma & $\begin{array}{l}\text { Multiple nodules and ulcers in sporotrichoid } \\
\text { pattern on right third and fourth digits and } \\
\text { distal forearm }\end{array}$ & $\begin{array}{l}\text { ITZ } 200 \mathrm{mg} / \mathrm{d} \text { for } 5 \text { months, then ITZ } 100 \\
\mathrm{mg} / \mathrm{d} \text { for } 1 \text { month }\end{array}$ & Cured \\
\hline 18 & $\begin{array}{l}\text { Hyde } \\
\text { et al. [24] }\end{array}$ & 2016 & $10 / \mathrm{F}$ & Unknown & Ulcerated nodule on right foot & No treatment & Cured \\
\hline 19 & $\begin{array}{l}\text { Henderson } \\
\text { and Dreyer } \\
{[25]}\end{array}$ & 2018 & $69 / \mathrm{M}$ & Trauma & Ulcer, bullous lesions, and edema on right arm & FCZ $400 \mathrm{mg} / \mathrm{d}$ for 1 year & Cured \\
\hline 20 & $\begin{array}{l}\text { Twede and } \\
\text { Peters [26] }\end{array}$ & 2018 & $28 / \mathrm{F}$ & $\begin{array}{l}\text { Trauma and } \\
\text { contact with avian ex- } \\
\text { creta }\end{array}$ & $\begin{array}{l}\text { Annular erythematous plaque lesions on } \\
\text { - shins and calves }\end{array}$ & $\begin{array}{l}\text { FCZ } 200 \text { mg twice daily for } \\
6 \text { months }\end{array}$ & Cured \\
\hline 21 & $\begin{array}{l}\text { Beatson } \\
\text { et al. [27] }\end{array}$ & 2019 & $80 / \mathrm{M}$ & Pigeon breeder & Ulcerated plaques on left cheek and right ear & FCZ $200 \mathrm{mg} / \mathrm{d}$ for 2 months & Cured \\
\hline 22 & Present case & 2021 & $60 / \mathrm{F}$ & Trauma & $\begin{array}{l}\text { Erythematous ulcered nodule, suppuration, } \\
\text { and central } \\
\text { necrosis of right thumb }\end{array}$ & $\begin{array}{l}\text { Surgery, then ITZ } 200 \mathrm{mg} / \mathrm{d} \text { daily for } 6 \\
\text { months }\end{array}$ & Cured \\
\hline
\end{tabular}

M, male; F, female; d, day; AMB, amphotericin B; FCZ, fluconazole; ITZ, itraconazole. 